\title{
Research Regarding Chemical Content and Nutritive Value of Hen Eggs Obtained in Two Different Rearing Systems
}

\author{
BOGDAN VLAD AVARVAREI ${ }^{1}$, LUCIA IULIANA NISTOR (COTFAS) ${ }^{1}$, DANIEL SIMEANU1*, ADRIAN MAXIMILIAN MACRI ${ }^{2 *}$ \\ ${ }^{1}$ University of Agricultural Sciences and Veterinary Medicine lasi, 3 Mihail Sadoveanu Alley, 700490, Iasi, Romania \\ 2University of Agricultural Sciences and Veterinary Medicine Cluj-Napoca, 3-5 Calea Manastur Str., 400372, Cluj-Napoca, \\ Romania
}

\begin{abstract}
Exploitation system of laying hens is a very important exogenous factor which influences both their morphproductive performances and also the qualitative characteristics of the obtained eggs. In the lastperiod of time the emphasis is increasingly high on egg production obtained from hens which were reared in alternative systems. But the opinions are quite diverse regarding the quality of eggs obtained through such systems. Having in view the multitude of opinions and especially the demands of consumers for eggs obtained in free range system, by the current paper we aimed to analyse from qualitative point of view the eggs obtained in such conditions. So, were analysed 100 eggs gathered from Lohmann Brown hens, distributed as follows: 50 eggs were gathered from hens exploited in free range system - batch LE and 50 eggs provided from hens reared in EU approved batteries - batch LC. Eggs were chemically analysed, through basic chemical analysis (were determined dry matter, water, organic substances, proteins, lipids, non-nitrogenous extractive substances and minerals) and physically by evaluation of mass, thickness of mineral shell, breaking up resistance and colouring level of yolk. At the end of research we noticed that eggs obtained in free range system had superior values for the majority of analysed parameters face to the eggs obtained in conventional system. However, the differences were very low, statistically insignificant, which means that also in conventional system could be obtained eggs with a very good quality. The sole parameter were differences were notable was yolk pigmentation, an indicator appreciated by the great majority of consumers.
\end{abstract}

Keywords: chemical content, physical indicators, yolk colour, conventional, free range

Egg represents one of the cheapest and most frequent consumed products with animal origin, with a major contribution for human nourishment. Egg is rich in high quality proteins. Moreover, is almost a complete source for minerals and vitamins [1, 2].

External and internal qualities of eggs are very important for consumers' health but also from perspective of marketing $[3,4]$.

Nowadays consumers of avian products had an increasing demand for products obtained in extensive rearing systems, such as free range, due to preoccupations regarding animals' welfare $[5,6]$.

The industry which produces those important foods in human nourishment replies to their preoccupations through an increasing of eggs production in free range system or in modified cages [ 7].

A suitable hens' rearing and nourishment technology present a great importance because must assure hens' health and welfare those one being reflected in the quality of obtained products [8].

In according with the actual regulations free range egg is obtained in aviary farms which practice a rearing technology in which hens have access to an external paddock, so will be able to provide their ethological and physiological instincts.

Egg is complete foods which play a very import role in day by day nourishment, no matter in which exploitation system was obtained. Alternative rearing systems, for laying hens became priority, from $1^{\text {st }}$ of J anuary 2012 , when classical batteries were banned and replaced with approved batteries, where the welfare notion is respected, but also by free range systems which allow the access of hens to external environment, fact beneficial on welfare but with lacks regarding nourishment security.

* email: dsimeanu@uaiasi.ro; adrian.macri@usamvcluj.ro
Hygiene and bio-security are very important notions not regarding only health of laying hens but also regarding consumers' health. In alternative systems, were hens have access to external environment, is accumulated a significant dust quantity, especially in area with permanent layer having as consequence a microbial contamination and with endotoxins of air. In 2005, De Reu et al. [9] demonstrated that the improvements made to alternative systems produced 10 times more bacteria in the existent micro-climate and by 20-30 times more micro-organisms at the level of mineral shell, in comparison with hen's exploitation in batteries. Eggs obtained in alternative systems have a contamination of shell generally produced by aerobe bacteria.

Messens et al., (2007) [10], demonstrated that the high microbial charge of micro-climate lead to an increasing of micro-organisms on mineral shell, fact which lead to their penetration inside egg.

Regarding quality of eggs obtained from hens reared in alternative systems, the opinions of specialists are divided. So, for example, Minelli etal. (2007) [11] affirm that eggs gathered from systems approved byEuropean Union had a decreased breaking up resistance of shell and an inferior quality of components while Hidalgo et al. (2008) [7] reported a higher weight of eggs and a better breaking up resistance that the eggs obtained in conventional systems.

It is well known the fact that nourishment represents the most suggestive indicator for increasing of life standard of mankind, so, from this reason, obtaining of food products with animal origin became a priority and permanent necessity, having in view the superiority of biological value of proteins contended by those [12].

Hen eggs represent a complete food, no matter of the exploitation system in which was obtained, being considered one of the most versatile nourishment sources [13]. 


\section{Experimental part}

Materials and methods

The studied material was represented by 100 eggs gathered from Lohmann Brown hens, distributed such as: 50 eggs were gathered from hens exploited in free range system - batch LE and 50 eggs from hens reared in EU approved batteries - batch LC.

Hens from both batches were feed with mixed fodders obtained after the same recipe; particularly the ones from free range system had access to external paddock which was sowed with grass.

Eggs' weight was determined on eggs gathered from those two batches and was realised with an analytical balance, determination of shell breaking up resistance was made with Schröder apparatus, based on the principle of application of an increasing pressure on egg placed with the round peak up, thickness of mineral shell was established by measuring with callipers for shell gathered from 3 distinct areas (round peak, median zone, sharp peak), after that the mean of those 3 measurements was made, yolk colour was appreciated at natural light, comparing La Roché standard scale with intensity of studied yolk colour, being analysed 900 samples.

Were made analysis on egg edible components (albumen, yolk and respectively melange), aiming to enlightening their content in water and dry matter; also, was established the rate of organic substance (proteins, lipids and non-nitrogenous extractive substances related to dry matter), as well as inorganic substance (crude ash). After breaking up and removal of shell, for each egg was separated albumen from yolk (50 samples), and after that we proceed to establish the chemical composition, for each of those two components. From the content of other samples (50 eggs) was obtained a mix in natural rate (melange), on which were made the same type of analysis.

Analysis were realised in according with the actual standards as follows:

-determination of water and dry matter content was made by samples drying in oven at $103 \pm 2^{\circ} \mathrm{C}$ for 6 hours, previously weighted, after obtaining a constant weight was quantified the dry matter and by calculus was determined the moisture of products [14];

-content in proteins was determined by Kjeldhal method, described in standard ISO 59836-1:2006/AC:2009 [15];

-content in fats was realised by extraction with organic solvents using Soxhlet method [16];

-mineral substances (crude ash) were determined by samples calcinations at $+550^{\circ} \mathrm{C}$ till a constant weight;

-organic substance, as well as non-nitrogenous extractive substances were established by mathematical calculus in according with the formulas: $\% O S=\% D M-\% C$. ash [17], respectively \%NES=\%OS-(\%CP+\%CF) [18-21].
To determine the nutritive value of components from analysed eggs was effectuated the calculus of caloricity using the theoretical formula based on quantity of gross caloric energy liberated atburning of one gram of proteins, fats and carbohydrates in bomb calorimeter, in according with formula [22-24]:

$\mathrm{GE}(\mathrm{kcal} / 100 \mathrm{~g})=5.70 \mathrm{kcal} \times \mathrm{g}$ proteins $+9.50 \mathrm{kcal} \times \mathrm{g}$ fats $+4.2 \mathrm{kcal} \times \mathrm{NES}$

\section{Results and discussions}

Physical quality indicators of studied eggs

External quality parameters of eggs could be evaluated from the point of view of mass, resistance and thickness of mineral shell as well as with other indicators such as: format index, incidence of hereditary morphological anomalies, dirtiness degree of shell [25].

In the current study we choose to present results regarding eggs' mass, their breaking up resistance and thickness of mineral shell, considering that those three parameters are the most important ones.

Eggs' mass is an important criterion for expressing the external qualities; consumers' demands are mainly focused on eggs which are in classes' $M$ and L (respectively between 53 and $73 \mathrm{~g}$ ).

Factors which influence eggs' mass are various such as genetic factors, quantitative and qualitative nourishment applied to hens, hens' mass, and also between them we can count the applied exploitation technology [26-28] .

At the end of the study conducted by us we noticed that eggs gathered from hens reared in free range system had a mass higher with $2.11 \%$ face to the one recorded for eggs obtained in conventional rearing system due to the nutritive advantages provided by food resources founded in paddock (table 1).

Statistically speaking the calculated differences between those two batches weren't significant, and the studied character was a homogenous one $(\mathrm{V} \%=6.62-7.10)$.

Breaking up resistance of shell is a very important parameter on the whole production chain; breaking or cracking of eggs destined for consumption cause economical losses (can't be sold) and create the risk for a bacterial contamination [29,30].

In alternative systems, resistance of mineral shell is very high, fact proved by studies conducted by authors such as Leyendecker et al. (2001) [31] etc.

From determinations realised on eggs obtained from studied hens resulted that statistically speaking, between those two systems weren't significant differences, but the best results were obtained at eggs gathered from hens reared in free range system. So, eggs from batch LE had a breaking up resistance higher with around $2.7 \%$.

Thickness of mineral shell is a parameter which decrease with hens aging [27], especially after the age of 36 weeks [32-35].

\begin{tabular}{|c|c|c|c|}
\hline $\begin{array}{c}\text { Analysed } \\
\text { parameters }\end{array}$ & Statistical estimators (n=100) & LC & LE \\
\hline \multirow{4}{*}{ Mass } & $\bar{X} \pm \mathrm{s} \bar{x}(\mathrm{~g})$ & $63.239 \pm 4.681$ & $64.577 \pm 4.918$ \\
\cline { 2 - 4 } & $\mathrm{V} \%$ & 6.620 & 7.102 \\
\cline { 2 - 4 } & Significance of differences & $\hat{F}=0.038 ; \mathrm{F} \alpha_{0.05}=5.317 ; \hat{F}<\mathrm{F}_{0.05} \rightarrow \mathrm{n} . \mathrm{s}$. \\
\hline \multirow{2}{*}{$\begin{array}{c}\text { Breaking up } \\
\text { resistance of } \\
\text { shell }\end{array}$} & $\bar{X} \pm \mathrm{s} \bar{x}\left(\mathrm{kgf}^{\prime} \mathrm{cm}^{2}\right)$ & $0.334 \pm 0.003$ & $0.343 \pm 0.003$ \\
\cline { 2 - 4 } & $\mathrm{V} \%$ & 0.001 & 0.001 \\
\cline { 2 - 4 } & Significance of differences & $\hat{F}=4.196 ; \mathrm{F} \alpha_{0.05}=5.317 ; \hat{F}<\mathrm{F}_{0.05} \rightarrow \mathrm{n} . \mathrm{s}$. \\
\hline \multirow{3}{*}{$\begin{array}{c}\text { Thickness of } \\
\text { shell }\end{array}$} & $\bar{X} \pm \mathrm{s} \bar{x}(\mathrm{~mm})$ & $0.388 \pm 0.018$ & $0.398 \pm 0.019$ \\
\cline { 2 - 4 } & $\mathrm{V} \%$ & 0.001 & 0.001 \\
\cline { 2 - 4 } & Significance of differences & $\hat{F}=0.154 ; \mathrm{F} \alpha_{0.05}=5.317 ; \hat{F}<\mathrm{F}_{0.05} \rightarrow \mathrm{n} . \mathrm{s}$. \\
\hline
\end{tabular}

Table 1

QUALITY PHYSICAL PARAMETERS OF ANALYSED EGGS 
Regarding exploitation systems of laying hens, we observed a higher thickness of shell for eggs gathered from alternative systems in comparison with conventional batteries [36-39].

In the current study we noticed that at eggs gathered from batch LE thickness of mineral shell was $0.398 \mathrm{~mm}$, with $2.57 \%$ higher that in case of eggs from batch LC [40].

In conclusion we can affirm that hens reared in free range system could provide eggs with physical properties slightly high than hens reared in conventional system, but must be mentioned the fact that the obtained differences weren't statistically significant for none of the analysed physical parameters.

\section{Quality chemical indicators of studied eggs}

Egg have a low energy/protein rate, which make it suitable for diets with a moderate caloric level; if it is combined the coefficient of digestive utilisation and biological value, practical utilisation of proteins from whole egg reaches $94 \%$, in comparison with $84.3 \%$ for milk, $76 \%$ for fish or $74.3 \%$ for beef meat $[41,42]$.

At the end of realised research, we observed that chemically speaking eggs obtained from hens reared in free range system had superior mean values face the eggs obtained in conventional rearing system (table 2).

So, speaking about dry matter content we obtained for batch LE a value higher with 3.87\% face to batch LC, difference which wasn't statistically significant.

Content in protein of eggs gathered from hens reared in free range system was $11.82 \%$, with $5.1 \%$ higher than mean recorded for eggs obtained in conventional hens rearing system; differences weren't statistically significant. Rate energy/protein calculated in both situations was 14.33 at batch LC and 14.25 at batch LE.

Superior mean values were calculated at batch LE face to batch LC also for organic substance $(+4.2 \%)$ and fats $(+4.8 \%)$; but, eggs gathered from free range rearing had lower means for non-nitrogenous extractive substances content (-8.31\%) and for minerals content (-2.83\%). In none of situations weren't observed significant statistically differences.

In conclusion, we could say that chemically speaking, eggs obtained in free range system are superior to the ones obtained in conventional rearing system but without significant statistically differences.

The data obtained by us are in concordance with the results obtained by other authors, so in case of melange the content in dry matter was lower at eggs obtained in conventional system, values being between 23.50 and $23.92 \%$, face to the ones obtained in free range system $(23.6-25.68 \%)[7,43]$. In the case of protein content, the obtained data for conventional eggs were between $12.10 \%$ and $12.42 \%$, and for the ones obtained from hens reared in free range system between $12.50 \%$ and $13.03 \%$ [44, 45], also, existed slightly differences in case of lipids content where the values were between $7.11 \%$ and $10.03 \%$ [34, $46,47]$.

The same situation was highlighted at chemical analysis of yolk of studied eggs. So, eggs from batch LE dry matter content of yolk was with 1.9\% higher than at eggs from batch LC - insignificant statistically differences (table 3).

\begin{tabular}{|c|c|c|c|}
\hline Analysed parameters & $\begin{array}{l}\text { Statistical estimators } \\
(\mathrm{n}=50)\end{array}$ & LC & LE \\
\hline \multirow{3}{*}{ Water } & $\bar{X} \pm s \bar{x}(\%)$ & $76.620 \pm 0.857$ & $75.713 \pm 0.688$ \\
\hline & $\mathrm{V} \%$ & 1.469 & 1.166 \\
\hline & Significance of differences & \multicolumn{2}{|c|}{$\begin{array}{c}\hat{F}=0.562 ; \mathrm{F} \alpha_{0.05}=5.317 \\
\hat{F}<\mathrm{F}_{0.05} \rightarrow \text { n.s. }\end{array}$} \\
\hline \multirow{3}{*}{$\mathrm{DM}$} & $\overline{\bar{X}} \pm \mathrm{s} \bar{x}(\%)$ & $23.380 \pm 0.857$ & $24.287 \pm 0.688$ \\
\hline & $\mathrm{V} \%$ & 0.448 & 0.372 \\
\hline & Significance of differences & \multicolumn{2}{|c|}{$\begin{array}{c}\hat{F}=0.562 ; F \alpha_{0.05}=5.317 ; \\
\hat{F}<F_{0.05} \rightarrow \text { n.s. }\end{array}$} \\
\hline \multirow{3}{*}{ OS } & $\overline{\bar{X}} \pm_{\mathrm{s}} \bar{x}(\%)$ & $22.146 \pm 0.870$ & $23.088 \pm 0.687$ \\
\hline & $\mathrm{V} \%$ & 0.433 & 0.353 \\
\hline & Significance of differences & \multicolumn{2}{|c|}{$\begin{array}{c}\hat{F}=0.416 ; F \alpha_{0.05}=5.317 ; \\
\hat{F}<F_{0.05} \rightarrow \text { n.s. }\end{array}$} \\
\hline \multirow{3}{*}{$\mathrm{CP}$} & $\overline{\bar{X}} \pm \mathrm{s} \bar{x}(\%)$ & $11.246 \pm 0.394$ & $11.820 \pm 0.252$ \\
\hline & $\mathrm{V} \%$ & 0.099 & 0.066 \\
\hline & Significance of differences & \multicolumn{2}{|c|}{$\begin{array}{c}\hat{F}=1.509 ; F \alpha_{0.0 s}=5.317 \\
\hat{F}<F_{0.05} \rightarrow \text { n.s. }\end{array}$} \\
\hline \multirow{3}{*}{$\mathrm{CF}$} & $\overline{\bar{X}} \pm s \bar{x}(\%)$ & $9.686 \pm 0.145$ & $10.155 \pm 0.142$ \\
\hline & $V \%$ & 0.031 & 0.032 \\
\hline & Significance of differences & \multicolumn{2}{|c|}{$\begin{array}{c}\hat{F}=5.309 ; F \alpha_{0.05}=5.317 \\
\hat{F}<\mathrm{F}_{0.05} \rightarrow \text { n.s. }\end{array}$} \\
\hline \multirow{3}{*}{ NES } & $\overline{\bar{X}} \pm \mathrm{s} \bar{x}(\%)$ & $1.214 \pm 0.102$ & $1.113 \pm 0.467$ \\
\hline & $\mathrm{V} \%$ & 0.003 & 0.009 \\
\hline & Significance of differences & \multicolumn{2}{|c|}{$\begin{array}{c}\hat{F}=1.734 ; F_{\alpha} 0.05=5.317 \\
\hat{F}<F_{0.05} \rightarrow \text { n.s. }\end{array}$} \\
\hline \multirow{3}{*}{ C. ash } & $\overline{\bar{X}} \pm \mathrm{s} \bar{x}(\%)$ & $1.234 \pm 0.063$ & $1.199 \pm 0.072$ \\
\hline & $\mathrm{V} \%$ & 0.001 & 0.001 \\
\hline & Significance of differences & \multicolumn{2}{|c|}{$\begin{array}{c}\hat{\hat{F}}=1.277 ; \mathrm{F}_{0.05}=5.317 ; \\
\hat{F}<\mathrm{F}_{0.05} \rightarrow \text { n.s. }\end{array}$} \\
\hline \multirow{2}{*}{ Energy } & $\mathrm{kcal} / 100 \mathrm{~g}$ & 161.22 & 168.52 \\
\hline & $\mathrm{kJ} / 100 \mathrm{~g}$ & 673.89 & 704.41 \\
\hline
\end{tabular}

Table 2

CHEMICAL COMPOSITION AND ENERGETIC VALUE OF EGGS 


\begin{tabular}{|c|c|c|c|}
\hline Analysed parameters & $\begin{array}{c}\text { Statistical estimators } \\
(n=50)\end{array}$ & LC & LE \\
\hline \multirow{3}{*}{ Water } & $\bar{X} \pm 3 \bar{x}(\%)$ & $51.131 \pm 0.628$ & $50.203 \pm 0.823$ \\
\hline & $\mathrm{V} \%$ & 0.718 & 0.924 \\
\hline & Significance of differences & \multicolumn{2}{|c|}{$\begin{array}{c}\hat{\hat{F}}=0.803 ; \mathrm{F} \alpha_{0.05}=5.317 \\
\hat{F}<\mathrm{F}_{0.05} \rightarrow \text { n.s. }\end{array}$} \\
\hline \multirow{3}{*}{ DM } & $\bar{X} \pm s \bar{x}(\%)$ & $48.869 \pm 0.628$ & $49.797 \pm 0.823$ \\
\hline & $\mathrm{V} \%$ & 0.687 & 0.916 \\
\hline & Significance of differences & \multicolumn{2}{|c|}{$\begin{array}{c}\hat{\hat{F}}=0.803 ; \text { F } \alpha_{0.05}=5.317 \\
\hat{F}<\mathrm{F}_{0.05} \rightarrow \text { n.s. }\end{array}$} \\
\hline \multirow{3}{*}{ OS } & $\overline{\bar{X}} \pm s \bar{x}(\%)$ & $47.182 \pm 0.635$ & $48.077 \pm 0.800$ \\
\hline & $\mathrm{V} \%$ & 0.670 & 0.860 \\
\hline & Significance of differences & \multicolumn{2}{|c|}{$\begin{array}{c}\hat{\hat{F}}=0.765 ; \mathrm{F} \alpha_{0.05}=5.317 \\
\hat{F}<\mathrm{F}_{0.05} \rightarrow \text { n.s. }\end{array}$} \\
\hline \multirow{3}{*}{$\mathrm{CP}$} & $\bar{X} \pm s \bar{x}(\%)$ & $16.928 \pm 0.302$ & $17.329 \pm 0.267$ \\
\hline & $V \%$ & 0.114 & 0.103 \\
\hline & Significance of differences & \multicolumn{2}{|c|}{$\begin{array}{c}\hat{F}=0.982 ; \mathrm{F}_{0.05}=5.317 \\
\hat{F}<\mathrm{F}_{0.05} \rightarrow \text { n.s. }\end{array}$} \\
\hline \multirow{3}{*}{$\mathrm{CF}$} & $\bar{X} \pm s \bar{x}(\%)$ & $28.372 \pm 0.632$ & $28.922 \pm 0.782$ \\
\hline & $\mathrm{V} \%$ & 0.401 & 0.782 \\
\hline & Significance of differences & \multicolumn{2}{|c|}{$\begin{array}{c}\hat{\hat{F}}=0.300 ; \mathrm{F} \alpha_{0.05}=5.317 \\
\hat{F}<\mathrm{F}_{0.05} \rightarrow \text { n.s. }\end{array}$} \\
\hline \multirow{3}{*}{ NES } & $\overline{\bar{X}} \pm \mathrm{s} \bar{x}(\%)$ & $1.882 \pm 0.403$ & $1.826 \pm 0.401$ \\
\hline & $\mathrm{V} \%$ & 0.016 & 0.016 \\
\hline & Significance of differences & \multicolumn{2}{|c|}{$\begin{array}{c}\hat{\hat{F}}=0.011 ; \mathrm{F} \alpha_{0.05}=5.317 \\
\hat{F}<\mathrm{F}_{0.05} \rightarrow \text { n.s. }\end{array}$} \\
\hline \multirow{3}{*}{ C. ash } & $\overline{\bar{X}} \pm \mathrm{s} \bar{x}(\%)$ & $1.687 \pm 0.120$ & $1.720 \pm 0.122$ \\
\hline & $\mathrm{V} \%$ & 0.004 & 0.004 \\
\hline & Significance of differences & \multicolumn{2}{|c|}{$\begin{array}{c}\hat{\hat{F}}=0.038 ; \mathrm{F} \alpha_{0.05}=5.317 \\
\hat{F}<\mathrm{F}_{0.05} \rightarrow \text { n.s. }\end{array}$} \\
\hline \multirow{2}{*}{ Energy } & $\mathrm{kcal} / 100 \mathrm{~g}$ & 373.93 & 381.20 \\
\hline & $\mathrm{kJ} / 100 \mathrm{~g}$ & 1563.02 & 1593.41 \\
\hline
\end{tabular}

Table 3

CHEMICAL COMPOSITION AND ENERGETIC VALUE OF YOLK

Also insignificant were the observed differences for content in organic substance, protein, fats and minerals even if ateggs obtained in free range system those chemical parameters were superior to the ones obtained at batch LC with: 1.8\% for OS, 2.3\% for CP, 1.9\% for CF and C. ash.

Yolk of eggs obtained in conventional rearing system presented higher values face to the one obtained in free range system only for content in non-nitrogenous extractive substances $(+2.9 \%)$ and water $(+1.8 \%)$.

Rate energy/protein was 22.09 at batch LC and 21.99 at batch LE.

The obtained mean values at the end of analysis of yolk from studied eggs show superior data, for majority of parameters, for batch LE face to batch LC, but differences aren't statiscally significant.

The literature reveals for fat content of yolk higher values for eggs gathered from hens reared in free range system; so Radu-Rusu et al. (2012) [48] obtained $25.39 \%$ vs. $25.42 \%$ (conventional), Cherian etal. (2002) [49] mentioned values of $24.60 \%$ and $22.90 \%$ for conventional system; and values recorded by Krawcyzk et al. (2010) [50], revealed a fat content for eggs gathered from hens reared in open air of $29.7 \%$. Regarding protein input the founded values were lower than the ones founded by Yenice et al. (2016) [51] (14.23\% conventional and $15.25 \%$ - free range).

Similar results were determined after chemical analysis of albumen. So, eggs obtained in free range system had a richer albumen face to the one of eggs obtained in convention rearing system for: dry matter with $3.62 \%$, organic substance with $3.44 \%$, protein with $3.46 \%$, lipids with $5.78 \%$, non-nitrogenous extractive substances with $2.84 \%$ and for minerals with $5.93 \%$ (table 4 ).

As in previous situations, water content of albumen from hens reared in conventional system was higher face to the one of the hens freely reared $(+0.5 \%)$.

Rate energy/protein was 6.09 for albumen of eggs obtained in conventional system and 6.10 in case of albumen obtained in free range system.

As in the case of yolk was observed the fact that even was differences those ones weren't statistically significant.

An outstanding importance for albumen composition is given by protein content which had similar values to the ones cited in literature. So, Rizzi et al. (2015) and Miao et al. $(2005)[52,53]$ founded a content of $11.60 \%$ proteins for conventional system and $11.50 \%$ for free range system, and Yenice et al. (2016), Stanley et al. (2013), Tercic et al. (2012) [51, 54, 55] presented values for protein of $10.72 \%$ - conventional system and $11.01 \%$ for eggs gathered from hens reared in open air.

Colour of yolk is a decisive parameter for consumers regarding internal quality of hen eggs. Intensity of yolk colouring is influenced by rich nourishment in carotenoids, xantophyll isomers, lutein and zeaxanthin administrated to laying hens $[56,57]$.

Studies effectuated by Leth et al. (2000), Roll et al., (2009) $[58,59]$ show that in eggs provided from alternative systems were founded 2-3 times higher concentrations in lutein, in comparison with the ones provided from conventional systems.

From those 450 eggs gathered from batch LC hens $34.44 \%$ had the yolk placed on 7 colouring sample of $L a$ Roché scale - intense yellow, $45.56 \%$ on 8 sample -very 


\begin{tabular}{|c|c|c|c|}
\hline Analysed parameters & Statistical estimators $(n=50)$ & LC & LE \\
\hline \multirow{3}{*}{ Water } & $\bar{X} \pm s \bar{x}(\%)$ & $88.039 \pm 0.047$ & $87.606 \pm 0.077$ \\
\hline & $\mathrm{V} \%$ & 0.009 & 0.152 \\
\hline & Significance of differences & \multicolumn{2}{|c|}{$\begin{array}{c}\hat{F}=4.639 ; \mathrm{F}_{0.00}=5.317 ; \\
\hat{F}<\mathrm{F}_{0.05} \rightarrow \text { n.s. }\end{array}$} \\
\hline \multirow{3}{*}{ DM } & $\overline{\bar{X}} \pm \mathrm{s} \bar{x}(\%)$ & $11.961 \pm 0.047$ & $12.394 \pm 0.077$ \\
\hline & $V \%$ & 0.012 & 0.021 \\
\hline & Significance of differences & \multicolumn{2}{|c|}{$\begin{array}{c}\hat{F}=4.639 ; \mathrm{F}_{0.05}=5.317 ; \\
\hat{F}<\mathrm{F}_{0.05} \rightarrow \text { n.s. }\end{array}$} \\
\hline \multirow{3}{*}{ OS } & $\overline{\bar{X}} \pm \mathrm{s} \bar{x}(\%)$ & $11.135 \pm 0.048$ & $11.519 \pm 0.118$ \\
\hline & $\mathrm{V} \%$ & 0.012 & 0.030 \\
\hline & Significance of differences & \multicolumn{2}{|c|}{$\begin{array}{c}\hat{F}=0.564 ; F \alpha_{0.05}=5.317 \\
\hat{F}<F_{0.05} \rightarrow \text { n.s. }\end{array}$} \\
\hline \multirow{3}{*}{$\mathrm{CP}$} & $\overline{\bar{X}} \pm \mathrm{s} \bar{x}(\%)$ & $10.312 \pm 0.247$ & $10.669 \pm 0.218$ \\
\hline & $V \%$ & 0.057 & 0.052 \\
\hline & Significance of differences & \multicolumn{2}{|c|}{$\begin{array}{c}\hat{F}=1.246 ; \mathrm{F}_{0.05}=5.317 ; \\
\hat{F}<\mathrm{F}_{0.05} \rightarrow \text { n.s. }\end{array}$} \\
\hline \multirow{3}{*}{$\mathrm{CF}$} & $\overline{\bar{X}} \pm \mathrm{s} \bar{x}(\%)$ & $0.121 \pm 0.015$ & $0.128 \pm 0.016$ \\
\hline & $\mathrm{V} \%$ & 0.001 & 0.001 \\
\hline & Significance of differences & \multicolumn{2}{|c|}{$\begin{array}{c}\hat{F}=0.764 ; F \alpha_{0.05}=5.317 ; \\
\hat{F}<F_{005} \rightarrow \text { n.s. }\end{array}$} \\
\hline \multirow{3}{*}{ NES } & $\overline{\bar{X}} \pm \mathrm{s} \bar{x}(\%)$ & $0.702 \pm 0.159$ & $0.722 \pm 0.103$ \\
\hline & $\mathrm{V} \%$ & 0.002 & 0.001 \\
\hline & Significance of differences & \multicolumn{2}{|c|}{$\begin{array}{c}\hat{F}=2.154 ; F \alpha_{0.05}=5.317 ; \\
\hat{F}<F_{0.05} \rightarrow \text { n.s. }\end{array}$} \\
\hline \multirow{3}{*}{ C. ash } & $\overline{\bar{X}} \pm \mathrm{s} \bar{x}(\%)$ & $0.826 \pm 0.040$ & $0.875 \pm 0.049$ \\
\hline & $V \%$ & 0.001 & 0.001 \\
\hline & Significance of differences & \multicolumn{2}{|c|}{$\begin{array}{c}\hat{F}=2.446 ; F \alpha_{0.05}=5.317 ; \\
\hat{F}<F_{0.05} \rightarrow \text { n.s. }\end{array}$} \\
\hline \multirow{2}{*}{ Energy } & $\mathrm{kcal} / 100 \mathrm{~g}$ & 62.87 & 65.06 \\
\hline & $\mathrm{kJ} / 100 \mathrm{~g}$ & 262.79 & 271.95 \\
\hline
\end{tabular}

\begin{tabular}{|c|c|c|c|c|}
\hline \multirow{2}{*}{$\begin{array}{c}\text { Marks accorded in according } \\
\text { with La Roché scale }(\mathrm{n}=900)\end{array}$} & \multicolumn{2}{|c|}{ LC } & \multicolumn{2}{c|}{ LE } \\
\cline { 2 - 5 } & pieces & $\%$ & pieces & $\%$ \\
\hline 7 & 155 & 34.44 & 90 & 20.00 \\
\hline 8 & 205 & 45.56 & 175 & 38.89 \\
\hline 9 & 90 & 20.00 & 140 & 31.11 \\
\hline 10 & - & - & 45 & 10.00 \\
\hline
\end{tabular}

Table 4

CHEMICAL COMPOSITION AND ENERGETIC VALUE OF ALBUMEN intense yellow and only $20 \%$ on 9 colouring sample very light orange (table 5 ).

In case of eggs gathered from hens exploited in free range system, only $20 \%$ had a yolk colour scored with 7 , but $38.89 \%$ had the yolk scored with $8,31.11 \%$ scored with 9 , and $10 \%$ were placed in La Roche 10 colouring sample - light orange.

The reduced pigmentation of yolk of eggs gathered from conventional system was attributed to hens' nourishment, which was lacked of natural sources for xantophyll pigments offered by consumption of vegetation from the paddock which is external to the shelter in which hens are reared in free range system.

\section{Conclusions}

At the end of the research regarding quality of eggs obtained in those two exploitation systems (conventional -approved battery and alternative-free range) result a series of conclusions as follows.

Regarding the analysed physical indicators, we observed that eggs provided by hens reared in free range system had a mass of $64.577 \mathrm{~g}$, breaking up resistance of shell was $0.343 \mathrm{kgf} / \mathrm{cm}^{2}$ and thickness of mineral shell was $0.398 \mathrm{~mm}$. These values were superior to the ones obtained for eggs from conventional rearing system with: $2.11 \%$ for mass, $2.7 \%$ for breaking up resistance and with $2.57 \%$ for thickness of shell.

Chemically and energetically speaking, were differences between those two batches but those ones weren't statistically significant. Lightly superior mean values were obtained at batch LE for melange but also for albumen or yolk, fact which allowed us to affirm that eggs obtained in free range rearing system of hens are superior to the ones obtained in conventional system.

Colouring of yolk at eggs obtained in free range system was better because the rate of 8,9 and 10 scores was met in $80 \%$ of cases. Obtaining of eggs with a very intense yellow pigmentation till light orange could be an effect of the fact thathens reared in free range system benefited by vegetation rich in xantophyll pigments.

Even if eggs obtained in free range system had superior values to the ones obtained in conventional system, we consider that the differences are very small which means that also in conventional system could be obtained eggs with a good quality. The sole parameter where the differences were notable was yolk pigmentation, an indicator especially appreciated by the large mass of consumers. 


\section{References}

1.SPARKS, N.H.C., Poultry Science J ournal, 62, 2006, p. 308.

2.RATU, R.N., USTUROI, M.G., SIMEANU, D., SIMEANU, C., USTUROI, A., DOLIS, M.G., Mat. Plast., 54, no. 2, 2017 p. 368.

3.OZBEY, O., ESEN F., Poultry Science, 86, 2007, p. 782.

4.USTUROI, A., SIMEANU, C., USTUROI, M.G., DOLIS, M.G., RATU, R.N., SIMEANU D., Mat. Plast., 54, no. 2, 2017 p. 380.

5.SILVERSIDES, F.G., SCOTT, T.A., Poultry Science, 80, 2001, p. 1240. 6.SILVERSIDES, F.G., KORVER, D.R., BUDGELL, K.L., Poultry Science, 85, 2006, p. 1136.

7.HIDALGO, A., ROSSI, M., CLERICI, F., RATTI, S., Food Chemistry, 106, 2008, p. 1301.

8.ANDERSON, K.E., The Journal of Applied Poultry Research, 18, 2009, p. 348.

9.DE REU, K., GRIJ SPEERDT, K, HEYNDRICKX, M, ZOONS, J, DE BAERE, K, UYTTENDAELE, M, DEBEVERE, J., HERMAN, L., British Poultry Science, 46, no. 2, 2005, p. 149.

10.MESSENS, W., GRIJSPEERDT, K., DE REU, K., DE KETELAERE, B., MERTENS, K., BAMELIS, F., KEMPS, B., DE BAERDEMAEKER, J., DECUYPERE, E., HERMAN, L., J ournal of Food Protection, 70, 2007, p. 623.

11.MINELLI, G., SIRRI, F., FOLEGATTI, E., MELUZZI, A., FRANCHINI, A., Italian J ournal of Animal Science, 58, 2007, p. 518.

12.VITS, A., WEIZENBURGER, H.H., DISTL, O., Poultry Science, 84, 2005, p. 1511.

13.MATT, D., VEROMANN, E., LUIK, A., Agronomy Research, 7, no. II, 2009, p. 662.

14.MANOLACHE, F.A., HANGANU, A., DUTA, D.E., BELC, N., MARIN, D.I., Rev. Chim. (Bucharest), 64, no. 1, 2013, p. 45.

15.IOVAN, M., RADU, F., ROTARU, L., Rev. Chim. (Bucharest), 67, no. 5, 2016, p. 902.

16.DOLIS, M.G., SIMEANU, C., USTUROI, A, SIMEANU, D., Rev. Chim. (Bucharest), 68, no. 1, 2017, p. 151.

17.NISTOR (COTFAS), L.I., ALBU, V, USTUROI, M.G., Bulletin of University of Agricultural Sciences and Veterinary Medicine ClujNapoca. Food Science and Technology, 71, no. 2, 2014, p. 119.

18.RADU-RUSU, R.M., USTUROI, M.G., LEAHU, A., AMARIEI, S., RADURUSU, C.G., VACARU-OPRIS, I., South African Journal of Animal Science, 44, no. 1, 2014, p. 33.

19.SIMEANU, C., PASARIN, B., BOISTEANU, P.C., SIMEANU, D., DOLIS, M.G., NACU, G., IGNAT, GABRIELA, HOHA, G.V., Rev. Chim. (Bucharest), 69, no. 10, 2018, p. 2837.

20.SIMEANU, C., SIMEANU, D., DOLIS, M.G., Research Journal of Biotechnology, 12, no. 2, 2017, p. 1.

21.CRISTE, F.L, MIERLITA, D., SIMEANU, D., BOISTEANU, P.C., POP, I.M., GEORGESCU, G., NACU, G., Rev. Chim. (Bucharest), 69, no. 9, 2018, p. 2454.

22.DOLIS, M.G., BOISTEANU, P.C., SIMEANU, D., Rev. Chim. (Bucharest), 68, no. 6, 2017, p. 1459.

23.LUP, F., POP, I.M., SIMEANU, D., VICAS, S., SIMEANU, C., MIERLITA, D., Rev. Chim. (Bucharest), 69, no. 1, 2018, p. 222.

24.SIMEANU, C., SIMEANU, D., POPA, A., USTUROI, A., BODESCU, D., DOLIS, M.G., Rev. Chim. (Bucharest), 68, no. 5, 2017, p. 1063.

25.APPLEBY, M.C., World's Poultry Science Journal, 40, 1991, p. 241. 26.VAN DEN BRAND, H., PARMENTIER, H.K., KEMP, B., British Poultry Science, 45, 2004, p. 745.

27.NYS, Y, BURLOT, T., DUNN, I.C., XXIII World's Poultry Congress, Brisbane, Australia, June 30-July 4, World's Poultry Science Association (Australian branch), 10, 2008, p. 113.

28.PETEK, M., ALPAY, F., GEZEN, S.S., CIBIK, R., Kafkas Üniv VetFak Derg, 15, 2009, p. 57.

29.ABRAHAMSSON, P., TAUSON, R., APPLEBY, M.C., Acta Agriculturae Scandinavica, Section A - Animal Science, 45, 1995, p. 286.

30.MERTENS, W., GRIJ SPEERDT, K., HERMAN, L., Worlds Poultry Science Journal, 61, 2005, p. 71.
31.LEYENDECKER, M.H.H., HARTUNG, J., KAMPHUES, J., RING, C., GLUNDER, G., AHLERS, C., SANDER, I, NEUMANN, U., DISTL, O., $1^{\text {st }}$ communication: Performance traits. Zuchtungskunde, 73, 2001, p. 209.

32.CURTIS, P.A., GARDNER, F.A., MELLOR, D.B., Poultry Science, 64, 1985, p. 302.

33.CURTIS, P.A., KERTH, L.K., ANDERSON, K.E., Poultry Science, 84 (Suppl. 1), 2005, p. 78.

34.ENGLMAIEROVA, N., TUNOVA, E., CHARVATOVA, V., SKRIVAN, M., Czech J. Anim. Sci., 8, 2014, p. 345.

35.CHOdOVÁ, D., TUMOVA, E., CHARVATOVA, V., Proc. XV Eur. Symp. on the Quality of Eggs and Egg Products, Bergamo. World's Poultry Sci. J., Suppl. 69, 2013, p. 1.

36.BATKOW SKA, J., BRODACKI, A., Archiv. Anim. Breed., 60, 2017, p. 87.

37.AHAMMED, M., CHAE, B.J., LOHAKARE, J., KEOHAVONG, B., LEE, M.H., LEE, S.J ., KIM, D.M., LEE, J.Y., OHH, S.J ., Asian Australas. J. Anim. Sci. 27, no. 8, 2014, p. 1196.

38.DUKIC-STOJ CIC, M., PERIC, L., BJ EDOV, S., MILOSEVIC, N., Biotech. Anim. Husbandry 25, 2009, p. 1103.

39.LEWKO, L., GORNOWICZ, E., Ann. Anim. Sci., 11, 2011, p. 607.

40.ROBERTS, J.R., Poultry Science Journal, 41, 2004, p. 161.

41.FERRANTE, V., LOLLI, S., VEZZOLI, G., CAVALCHINI, L.G., Italian Journal Animal Science, 8, 2009, p. 165.

42.HINCKE, M.T., NYS, Y., GAUTRON, J., MANN, K., RODRIGUEZNAVARRO, A.B., Front. Biosci. Special Edition on Biomineralization, 17, 2012, p. 1266.

43.KOVACSNE, G.K., KONRAD, S., International Scientific Conference on Sustainable Development \& Ecological Footprint, Sopron, Hungary, 2012.

44.GALIS, A.M., VAN, I., THEWIS, A., Scientific Papers, Animal Science, Series D, LV, 2012, p. 162.

45.PAVLOVSKI, Z., HOPIC, S., LUKIC, M., Anim Biotechnol. Husbandry, 17, 2001, p. 197.

46.ARBONA, D.V., HOFFMAN, J.B., ANDERSON, K.E., Poult. Sci., 88, 2009, p. 21.

47.NISTOR (COTFAS), L.I., ALBU, A., BUNDUC, V., USTUROI, M. G., Journal of Biotechnology, 185, 2014, p. S73.

48.RADU-RUSU, R.M., USTUROI, M.G., RADU-RUSU, C.G., VACARUOPRIS, I., Lucrari Stiintifice, Seria Zootehnie, 57, no. 17, 2012, p. 201. 49.CHERIAN, G., HOLSONBAKE, T.B., GOEGER, M.P., Poultry Science, 81, 2012, p. 30.

50.KRAWCZYK, J., GORNOWICZ, E., Arch. Geflugelk, 74, 2014, p. 1. 51.YENICE, G., KAYNAR, O., ILERITURK, M., HIRA, F., HAYIRLI, A., Czech J. Food Sci., 34, no. 4, 2016, p. 370.

52.RIZZI, L., SIMIOLI, M., MARTELLI, G., PAGANELLIANDL, R., SARDI, L., WPSA European Poultry Conference, 2015, p. 677.

53.MIAO, Z.H., GLATZ, P.C., RU, Y.J ., J ournal Animal Science, 18, 2005, p. 113.

54.STANLEY, V.G., NELSON, D., DALEY, M.B., Agrotechnology, 2, 2013, p. 100.

55.TEREIE, D., ZLENDER, B., HOLCMAN, A., Agro-knowledge J. University of Banjaluka, Faculty of Agriculture, 13, 2012, p. 555.

56.HAMMERSHOJ, M., STEENFELDT, S., XIII European Symposium on the Quality of Eggs and Egg Products, Turku, World's Poultry Science Association, 2009, p. 63.

57.MOSTERT, B.E., BOWES, E.H., WALT, J.C. South African J ournal of Animal Science, 25, 1995, p. 80.

58.LETH, T, JAKOBSEN, J., ANDERSEN, N.L., European Journal of Lipid Science and Technology, 102, 2000, p. 128.

59.ROLL, V.F.B., BRIZ, R.C., LEVRINO, G.A.M., Cienc. Rural, 39, 2009, p. 1527

Manuscript received: 26.09 .2018 